\title{
New Approaches in Landscape Analysis of the Bronze Age in Cen- tral-Western Sardinia: the Area of Mogoro (Oristano - Italy)
}

\author{
Riccardo Cicilloni \\ Department of History, Cultural Heritage and Territory, University of Cagliari (Italy) \\ email: r.cicilloni@unica.it
}

Giuseppina Ragucci

Ministry of Education, Universities and Research (Italy)

email: gragucci@tiscali.it

\section{Marco Cabras}

PhD Candidate, Doctorado en Historia y Artes - Arquelogía y Cultura Material, Universidad de Granada

(Spain)

marcocabras@correo.ugr.es

\section{Alberto Mossa}

Postgraduate student, Postgraduate School in Archaeological Goods, University of Cagliari (Italy) email: mossaalberto1@gmail.com

\section{Abstract}

Research on the prehistoric and proto-historic landscape in Sardinia (Italy) allows knowledge and analysis of the island's archaeological heritage. Besides, recent studies have aimed to delineate the type of relationship that the prehistoric and proto-historic societies established with the variegated Sardinian landscape in connection with the ways of articulation and territorial appropriation, without neglecting the important and fundamental aspect of economic organisation of the territory. From this point of view, we want to analyse, as a sample-area, the region that includes the communal territory of Mogoro, in central-western Sardinia. Particularly we studied the ways of anthropisation and fruition of the landscape in proto-historic age, with the objective to reconstruct, through the study of the settlements and the relationships among them, some of the economic and social aspects of those groups of nuragic culture that enjoyed this area from the Middle Bronze Age to the
Iron Age. The area of Mogoro has been intensively investigated from the half of the past century; the investigations then culminated with the stratigraphical investigation carried out beginning in 1994 near the site of Cuccurada, the main centre of an articulated territorial system including a rich network of monuments related to the nuragic civilisation, such as nuraghi, giants' tombs and villages. In this work we present the results obtained through various research methods: geomorphological analysis, spatial analyst GIS tools (Viewshed, Cost Surface and Least-cost path analyses) and multivariate analysis (cluster and principal components analysis) that allow us to set a new hypothesis on population dynamics in this area and to individuate, among proto-historical monuments, one or more homogeneous and distinguished groups, starting from a database that results from indexing geomorphological characteristics.

Keywords: Protohistory, Nuraghi, Landscape, GIS, Multivariate Analysis 


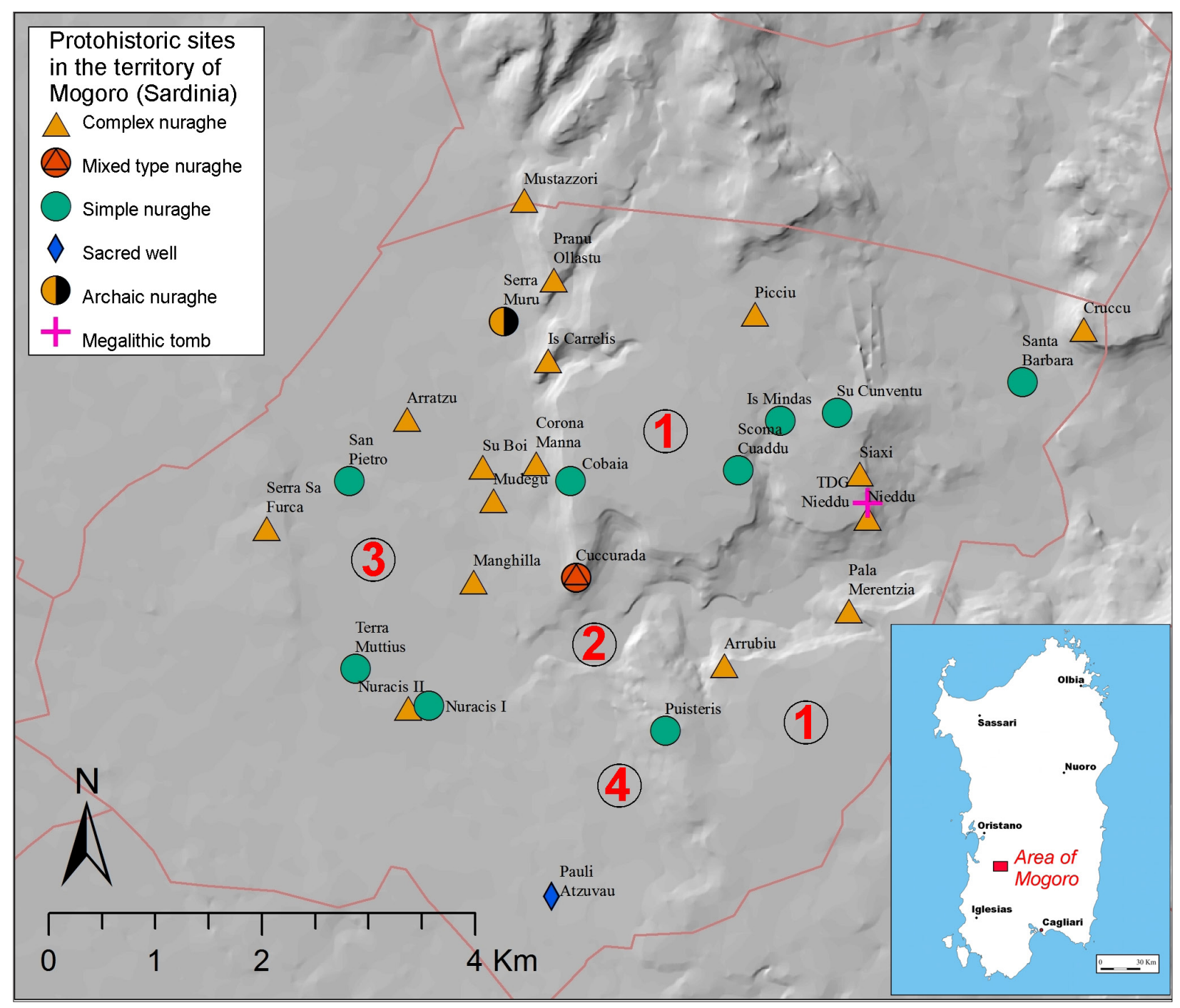

Fig. 1. Communal territory of Mogoro (Sardinia), distribution map of the nuragic sites (23rd-eighth century $\mathrm{BC}$ ). Geomorphological units: 1) basaltic plateau of Sa Struvina (NW) and Perdiana (SE); 2) Mogoro River Valley; 3) Campidano plain; 4) Marl and limestone formations.

\section{Introduction}

The territory that is the object of this work, is a sample-area, that corresponds to the communal territory of Mogoro, situated in the central-western Sardinia. This area is characterised by a great wealth of archaeological sites, above all from the Proto-Historic Age. Although this context defined by the administrative limits of a modern munici- pality is an arbitrary delimitation, the territory of Mogoro can be analysed as a significant area-sample, as it includes a well-defined and circumscribed geographical region consisting of the Rio Mogoro, this river basin is one of the oldest in Sardinia, and two plateaus, Perdiana and Sa Struvina which are to the north and south of the Rio. This region has attracted man since ancient times.

Currently we know 29 sites pertinent to the protohistoric period (fig. 1). Almost all sites contain "nuraghi", the typical large conical stone towers of Sardinia and in a site there is a giants' tomb, the collective burial contemporary of the Nuragic. The Nuragic civilisation was born in Sardinia in the Middle Bronze Age and spread throughout the island in the Late Bronze until the beginning of the 
Iron Age (23rd-eighth centuries BC) (Lilliu, 1988). We also detected a building of worship, a "sacred well", but chronologically it is later than the nuraghi and giants' tombs (Iron Age).

The purpose of this work is to analyse the relationship between the archaeological remains and the surrounding landscape, to find the modalities of taking possession and use of this territory by the proto-historic people, in order to obtain information about their society and economy.

For this study, we have used mainly geomorphological analyses, GIS analytical techniques and multivariate analyses. We want to point out, however, that the analysis carried out on this territory reveals some critical issues regarding both the exact typological definition and the precise chronology of the individual monuments. Almost all the structures are, in fact, in poor condition due to the collapse of the walls, which prevent a proper reading of the monuments and are very often hidden by abundant vegetation; moreover, among the monuments considered, only the nuraghe of Cuccurada has been object of archaeological excavations (Atzeni et al, 2005).

R.C.

\section{The territory}

For the study of the protohistoric sites in the Mogoro area, the methodology applied involves the breakdown of the territory in homogeneous geomorphological units, characterised by constant lithological and morphological patterns (Melis, 1998). In the territory of Mogoro we have identified four geomorphological units (fig. 1):

- Unit 1 "Struvina-Perdiana-Cruccu"; it includes a basaltic plateau divided by the river Rio Mogoro into two formations: one higher with steep slopes (Sa Struvina), the other of lower altitude, with more gentle slopes (Perdiana). The hydrology includes wetlands and groundwater aquifers.

- Unit 2 "Rio Mogoro"; it is constituted by a plain of piedmont type, originated from the alluvial cone of the river Rio Mogoro and it consists of flooding deposits transported downstream.

- Unit 3 "Central Campidano"; a plain, where small rivers flowed making alluvial deposits constituted by sand, gravel and lava related to the Quaternary. There is a presence of paleo-rivers and springs.

- Unit 4 "marl and limestone formations"; the Miocene deposits of marl and sandstone represent the formations underlying the basaltic plains.

If we divide the territory in elevation bands, more than half of the nuraghi falls in the middle range of the plains, a lower percentage in the low band of the floodplain, with only one monument on a hill, above $200 \mathrm{~m}$. a.s.l. The data also reflect the distribution of sites in the Landform units, where it is possible to see the absence of monuments in the alluvial soils of the Rio Mogoro (Landform unit 2) as they are subject to flooding.

We observe the highest percentage of nuraghi located on the plateau (Unit 1), equal to $52 \%$, and the corresponding high presence in the Campidano plain, with $41 \%$ of the monuments (Unit 3 ). Finally, there is a location on soils of Miocene formation (Unit 4 ) in which is situated only $7 \%$ of nuraghi. There is clearly a preference for sites in a position of great visual dominion, also observed in other territorial districts of Sardinia.

R.C.

\section{The Monuments}

The 29 sites referable to the nuragic period are divided by the basis of the typology of the monuments in 27 nuraghi, one giants' tomb and one sacred well. The $33 \%$ of the nuragic buildings in the territory is represented by nine nuraghi containing a simple tower, built either on the basaltic highlands or in the lowland. For the monumental aspect we mention the nuraghe of Guventu, a single tower located on the outskirts of the village of Mogoro. Also, the nuraghe Is Nuracis I appears interesting, situated on the plain a few metres away from the complex nuraghe Is Nuracis II. It could support the hypothesis of a simple use of these 


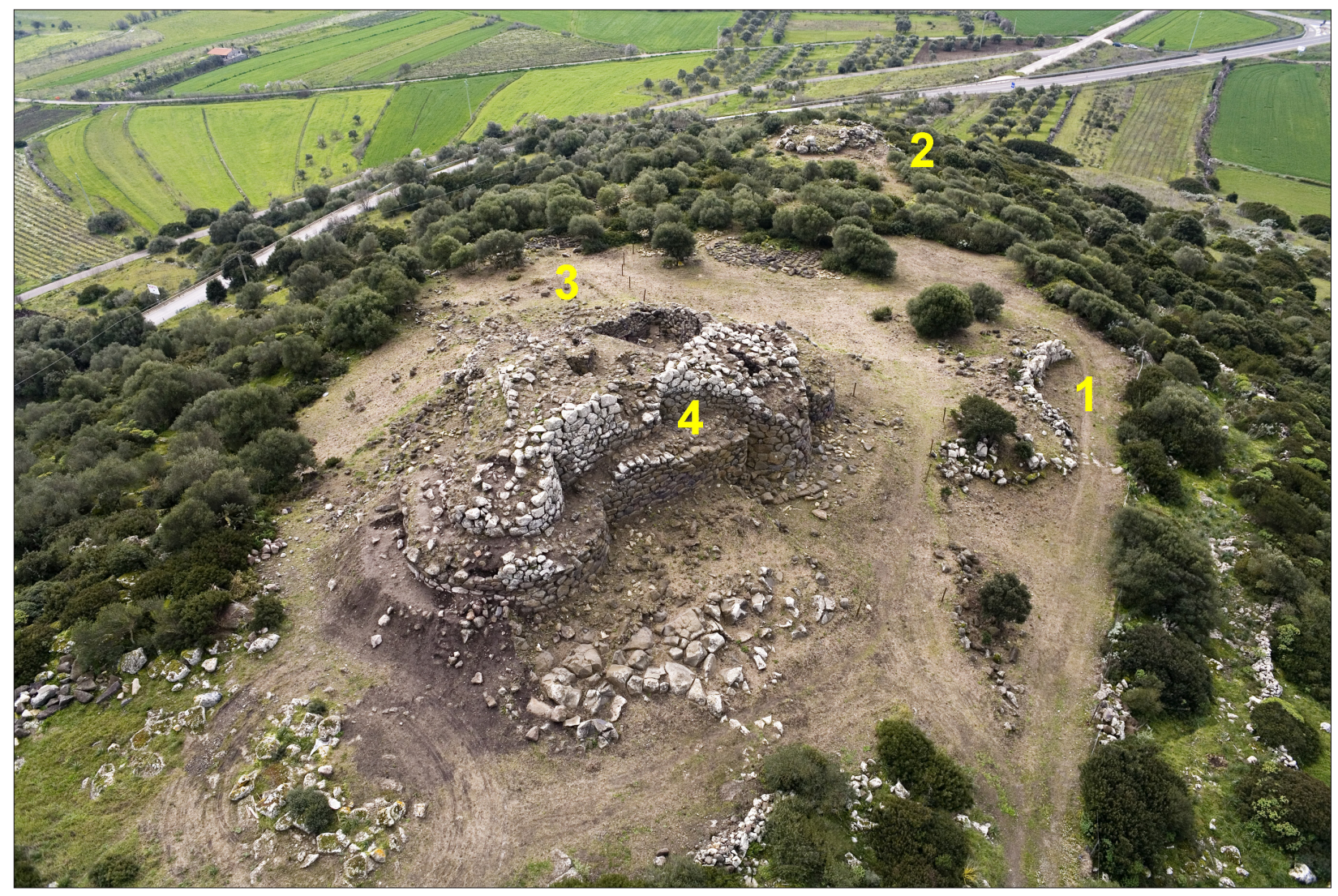

Fig. 2. Protohistoric site of Cuccurada - Mogoro (from north-west): 1) chalcolithic semicircular wall; 2) megalithic construction with elliptic plant of uncertain chronological attribution; 3) remains of proto-historic huts, 4) the complex nuraghe Cuccurada B.

towers not only as a look-out, if placed in a strategic location, but also as building support, with auxiliary function, in relation to a complex nuragic construction. They control the territory.

The complex nuraghi are more numerous (63\%). Among the complex nuraghi, the nuraghe Enna Pruna is constituted by a main tower of circular plan, to which a secondary tower has been added. The other two addition tangential nuraghi are Mudegu and Siaxi.

There are two complex nuraghi with longitudinal or transverse addition to the front (nuraghe Arratzu and Su Boil. The concentric addition type of nuraghi, real megalithic castles, are the most numerous. The archaeological site of Cuccurada includes
1) a chalcolithic semicircular wall,

2) a megalithic construction with an elliptic plan of uncertain chronological attribution,

3) remains of nuragic huts in the area of a precedent eneolithic settlement,

4) a complex nuraghe called Cuccurada B (fig. 2). The nuraghe has been the object of stratigraphical investigation and preserve traces of some phases of life. The monument has a nucleus consisting of the oldest primitive building la nuragic archaic structure typical of the Middle Bronze Agel with a kidney-shaped plan. Between the end of the Middle Bronze Age and Late Bronze, there was a general rearrangement of this structure, which has led to the construction of a type of nuraghe with the addition of a bastion composed by four perimeter towers, connected by straight walls, that delimit a great central courtyard (Atzeni et al, 2001; Cicilloni, 2007).

On the total of the nuragic monument characterised by a concentric addition, the nuraghi with three perimeter towers are more diffused than those with four towers. Among the trilobal ones, 
the nuraghe Pranu Ollastu is surely the most important. It has a central tower and three peripheral towers.

Among the tetralobal nuraghi, the nuraghe Nuracis II, is composed by a central tower and four secondary towers. In the area of Mogoro, archaeological research has brought to light a sepulchral structure, the giants' tomb of Nieddu, which shows a long corridor. Finally, the sacred well of Pauli Atzuvau is articulated in a staircase of eight monolithic steps leading to a cell containing a pit in the middle.

G.R.

\section{The Support of GIS to Spatial Analysis}

The Viewshed analysis (Conolly \& Lake, 2006; Wheatley \& Gillings, 2002) is an important tool that can assist, with the global spatial analysis techniques, the reconstruction of the characteristics of the settlement in nuragic civilization. Nowadays the poor state of preservation of the monuments and the changes in vegetation in respect at the Bronze Age, prevent a global view on the number of monuments and on the complexity of settlement. Therefore, we used a tool that allows us to reproduce situations no longer to be found easily except with an accurate field survey. This factor is caused either by changes in the current vegetation as compared to the old past, as mentioned, and by the lack of visibility found in some sites during surveys. The Viewshed analysis was then calculated with a radius of $360^{\circ}$ by an observer placed at $12 \mathrm{~m}$ above the ground in correspondence of each nuragic tower towards a radius of $5 \mathrm{~km}$.

An analysis of the minimum cost of distance was then carried out (Least-cost path analysis LCPA) (Conolly \& Lake, 2006; Wheatley \& Gillings, 2002); this sort of investigation tends to evaluate the organisational arrangements of the settlement on the basis of a network of tracks characterized by slopes terrains with natural easy travelling. These paths were probably functional for economic activity and trade relations between indigenous peoples and other nearby, or not so near, areas.
The Cost Surface Model has been calibrated using procedures of Reclass and Map algebra (Camerieri \& Mattioli, 2013; Casarotto, De Guio \& Ferrarese, 2009; Conolly \& Lake, 2006; Gherdevich, 2009; Pecere, 2006; Wheatley \& Gillings, 2002) taking into account the main parameters that affect movement through the territories: the degree of slope and the presence of wet areas, rivers and lakes. We have therefore linked external sites that crossed the study area; in this way it was possible to evaluate the relationship of the Least-cost paths with the sites subject of our analysis.

The results of the Viewshed analysis (fig. 3, a-d) have highlighted the visual persistence of monuments in areas that describe two models of settlement: one relating to the lowland areas to the West and another to plateau areas to the East. The analysis of the field of view has also demonstrated that these settlement units are interwoven between them through the connecting role played by certain monuments between an adjacent unit and another. These can be identified in several simple nuraghi such as Cobaia, Puisteris and in complex nuraghi such as Cuccurada and Serra Sa Furca. The latter complex is situated on a slight elevation compared to the surrounding plain and is equipped with excellent visual potential upon the surrounding territory, especially towards Perdiana plateau in the South and towards the northern portion of the Mogoro territory and Campidano of Uras. The nuraghi with greater visibility are Serra Sa Furca, Cobaia and Cuccurada: the placement of the first has already been mentioned. The second was built on the edge of the plateau of Struvina in view of the surrounding plains but also on the portion of land to the north of today's town of Mogoro and to the territory of Uras, Masullas and Siris, a strategic location that was made in a non-random way offering a lot more visibility than other areas closer by. The Cuccurada, finally, is located at the southern limit of a "spur" that departs from the plateau of Struvina in a southerly direction. The strategic location at the mouth of the river Rio Mogoro and towards the plain, makes it one of the monuments in this area strategically located for better visual control. This strategic position should persist from the early nuragic age and 


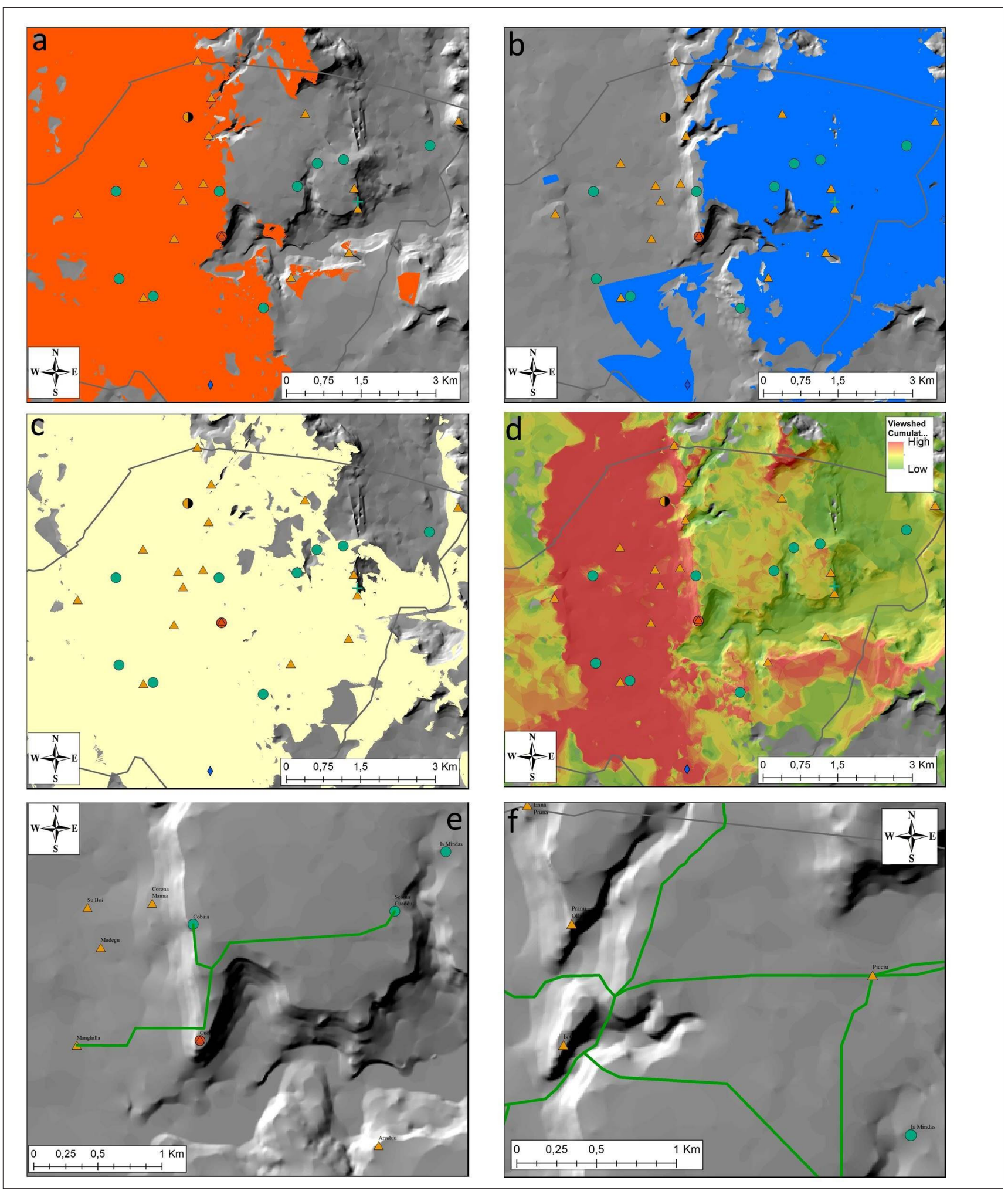

Fig. 3. Results of GIS analyses: a) Viewshed analysis on the monuments of the western sector; b) Viewshed analysis on the monuments of the eastern sector; c) Viewshed analysis of the monuments that link western and eastern sectors (Cobaia, Puisteris, Cuccurada and Serra Sa Furca); d) Cumulative Viewshed analysis on all the monuments of the study area; e) LCPA in the nuraghe Cuccurada area; f) LCPA in the Cortiaccas area. 
beyond, as demonstrated by the findings relating to the Chalcolithic period (Atzeni et al, 2001; Cicilloni, 2014). There are then many monuments with lower potential visual control compared to nuraghe Cuccurada, several with very small visual capacity which could probably be relevant to the direct control of transit areas. The monitoring on a larger scale would carried out by other peripheral structures, located on the edge of the plains or in close proximity to gullies, useful to climbing the plateau (ls Mindas, Scoma Cuaddu, Monte Itta, Pranu Ollastus, Enna Pruna).

This close relationship between settlements shows that the articulation of territory would seem the result of an almost systematic way to articulate the landscape brought forward in time. The lack of stratigraphic data on the life stages of these monuments, however, could distort our conclusions. In our opinion it could be a settlement system that was completed gradually over time according to the natural contours of the land. This factor gave to the builders of nuraghi a good chance of control of the surroundings. The great dynamism of terrain forms has encouraged the completion of the primary schedule settlement to further the demographic growth that occurred during this period of the Middle-Late Bronze Age of Sardinia. The complexes nuraghi have located at the edges of plateaus and in flatlands characterised by the best soils suited to agricultural work. In the country surrounding Mogoro, there are areas best suited for grazing, however there is a higher incidence of simple nuraghi such as Is Mindas and Scoma Cuaddu. These nuraghi control the gully (where the stream Gora Canali Aintru flows) that, from the Struvina plateau, descends towards the valley of Rio Mogoro. The visual check of these is complemented by the corresponding complex nuraghe of Pala Merentzia which occupies a strip of land that sticks out towards the North-West from the opposite Perdiana plateau. Noteworthy also is the nuraghe Su Cunventu, located in one of the points of maximum altitude of the municipal territory (180 m a.s.l.) and the nuraghe Santa Barbara further downstream just a few hundred metres from the Rio Mogoro.
The relationships of viewshed with the trails resulted from the Least-cost path Analysis has been highlighted for the majority of the nuragic towers (fig. 3, e-f). The analysis indicates two areas of particular interest, probably as natural access routes: the Rio Mogoro's valley to the South and the area of Cortiaccas, to the North-West of Mogoro. The Rio Mogoro's valley, in fact, is systematically controlled at the mouth, both in plain and on the edges of the plains, and along the Rio Mogoro up to the East on the border with Gonnostramatza and up to the North in the territory of Masullas. The Cortiaccas area, more to the north, is connected with gullies at Mount Itta and Pranu Ollastu and would appear as a crossroads area between Campidano and internal areas of Monte Arci. In this regard it is noted that the nuraghe Picciu would be in close proximity to several Least-cost paths which connect external monuments to the study area. Another sensitive area would be occupied by the nuraghe Cuccurada, in proximity of a natural access point at the Struvina plateau. M.C.

\section{The cluster Analysis}

The method of cluster analysis is a set of statistical techniques introduced into the prehistoric researches by F.R. Hodson (Hodson, 1969), perfected by I. Hodder and C.R. Orton (1976) and utilised, more recently, for the study of settlement hierarchies. The use of the Groups Analysis, in fact, can be a valuable tool for understanding the evolution of the settlement dynamics. For over ten years the Iberian team of the University of Granada (Department of Prehistory and Archaeologyl has obtained interesting scientific results on the protohistoric community organisation and on the role played by the nuraghi in the control of the territory and in the management of its resources. Regarding this matter, we include, for example, the works of J.A. Cámara Serrano and L. Spanedda on the coastal settlement system of the Gulf of Orosei, in Eastern Sardinia (Spanedda \& Cámara, 2007; Spanedda, Cámara \& Puertas, 2007; Spanedda, Cámara \& Salas, 2010). 


\begin{tabular}{|c|c|c|c|c|}
\hline \multirow[t]{2}{*}{$N^{\circ}$} & \multirow[t]{2}{*}{ Toponym } & \multicolumn{3}{|c|}{ Data (radius of $1 \mathrm{Km}$ ) } \\
\hline & & YCAIP & YCAI1 & YCAI2 \\
\hline 1 & Nuraghe Arratzu & 0,008 & 0,094 & 1,24 \\
\hline 2 & Nuraghe Arrubiu & 0,094 & 1 & 2,48 \\
\hline 3 & Nuraghe Cobaia & 0,076 & 0,92 & 2,77 \\
\hline 4 & Nuraghe Corona Manna & 0,049 & 0,52 & 1,89 \\
\hline 5 & Nuraghe Cruccu & 0,248 & 1 & 2,68 \\
\hline 6 & Nuraghe Cuccurada & 0,066 & 0,9 & 3,21 \\
\hline 7 & Nuraghe Is Carrelis & 0,058 & 0,89 & 2,63 \\
\hline 8 & Nuraghe Is Mindas & 0,092 & 0,75 & 1,28 \\
\hline 9 & Nuraghe Manghilla & 0,048 & 0,28 & 1,13 \\
\hline 10 & Nuraghe Mudegu & 0,053 & 0,33 & 1,36 \\
\hline 11 & Nuraghe Mustazzori & 0,078 & 0,71 & 2,47 \\
\hline 12 & Nuraghe Nieddu & 0,081 & 0,73 & 2,27 \\
\hline 13 & Nuraghe Nuracis I & 0,006 & 0,73 & 1,16 \\
\hline 14 & Nuraghe Nuracis II & 0,007 & 0,91 & 1,31 \\
\hline 15 & Nuraghe Pala Merentzia & 0,059 & 0,89 & 2,25 \\
\hline 16 & Nuraghe Picciu & 0,046 & 0,67 & 1,13 \\
\hline 17 & Nuraghe Pranu Ollastu & 0,079 & 0,85 & 2,62 \\
\hline 18 & Nuraghe Puisteris & 0,085 & 1 & 2,91 \\
\hline 19 & Nuraghe San Pietro & 0,011 & 0,93 & 1,25 \\
\hline 20 & Nuraghe Santa Barbara & 0,177 & 0,4 & 1,31 \\
\hline 21 & Nuraghe Scoma Cuaddu & 0,074 & 0,81 & 2,25 \\
\hline 22 & Nuraghe Serra Muru & 0,049 & 0,43 & 1,41 \\
\hline 23 & Nuraghe Serra Sa Furca & 0,015 & 0,87 & 1,59 \\
\hline 24 & Nuraghe Siaxi & 0,083 & 0,9 & 2,61 \\
\hline 25 & Nuraghe Su Boi & 0,054 & 0,34 & 1,39 \\
\hline 26 & Nuraghe Su Cunventu & 0,089 & 1 & 1,69 \\
\hline 27 & Nuraghe Terra Mutius & 0,027 & 0,73 & 1,2 \\
\hline 28 & Tomba dei Giganti Nieddu & 0,08 & 0,73 & 2,27 \\
\hline
\end{tabular}

Tab. 1. Seriation of the monuments and related variables.

The set of indexes refers to the monument and its spatial dimension, where the occupants practiced most of their activity within a radius of $1 \mathrm{~km}$ (Spanedda, 2006). For each context, it is necessary to know four things: the height above sea level of the monument, the maximum height and the minimum of the surrounding landscape, and the distance between these points. These values are correlated with one another in different combina- tions, depending on the results to be obtained.

Through the hierarchical cluster analysis with Euclidean distance squared, we have developed a dendrogram, the reading of which must be closely related to each of the scatter graphs of points. The application of the statistical method was performed exclusively for the phase of the Middle and Late Bronze Ages. The following indexes relate to the settlement and the land surrounding it in an effective range of $1 \mathrm{~km}$, where the nuragic people were involved in most of their activities.

1) YCAIP (Index of Geomorphologic Area Gradient); it determine the relationship between the site and the elements surrounding it, more specifically the influence of the topographical 
characteristics of these surroundings upon subsistence-related resources and, most especially, upon the natural obstacles that favour or influence the control and the strategic functions. It is obtained by calculating the difference between the maximum and minimum heights in the Geomorphologic Area divided by the distance between these two points.

2) Visual Dominion Index 1 (YCAl1) associates the maximum height of the site with the maximum height of the area in order to understand if the site selection was motivated by strategic objectives. It is obtained by dividing the site's height by the maximum height within the surrounding area.

3) Visual Dominion Index 2 (YCAI2) associates the maximum height of the site with the minimum height of the area in order to identify dependent settlements. It is obtained by dividing the maximum height of the site by the minimum height of the area.

In this case study we have carried out a single analysis on the global control of the territory, which confirmed the real spatial position of the nuraghi, the only one that has provided a satisfactory result, using only the Index of Geomorphologic Area Gradient (YCAIP), correlated with those of Visual Dominion 2 (YCAI2). The combination of these factors has brought to light the capacity of the nuragic building to have a wide-ranging control, so it was possible to establish a clear hierarchy and adopt a territorial management model (tab. 1).

The analysis of the main components was carried out using all the obtained indices: the results show that the percentage of variance accumulated in the first component is of $61,04 \%$; the data, already important in itself, presents a difference of only $26 \%$ compared to that of the second component with value equal to $87.75 \%$ (tab. 2).

The correlation between the variables are not globally high, with the exception of the relationship between the gradient index of the geomorphologic area and the visual dominion 2 (0.586); the correlation between the two visual dominion indexes 1 and 2 (YCAI1 and YCAI2) is equally high $(0,421)$. Among the correlations with very low values, we

\begin{tabular}{|l|l|l|l|}
\hline \multirow{2}{*}{ Component } & \multicolumn{3}{|l|}{ Initial Eigenvalues } \\
\cline { 2 - 4 } & Total & $\begin{array}{l}\% \text { of vari- } \\
\text { ance }\end{array}$ & $\begin{array}{l}\text { \% accumu- } \\
\text { lated }\end{array}$ \\
\hline 1 & 1,831 & 61,04 & 61,04 \\
\hline 2 & 0,801 & 26,71 & 87,75 \\
\hline 3 & 0,367 & 12,25 & 100 \\
\hline
\end{tabular}

Tab. 2. Values and variances of the analysis on the main components.

\begin{tabular}{|l|l|l|l|l|}
\hline \multicolumn{2}{|c|}{} & YCAIP & YCAI1 & YCAI2 \\
\hline Correlation & YCAIP & 1 & 0,212 & 0,421 \\
\cline { 2 - 5 } & YCAI1 & 0,212 & 1 & 0,586 \\
\cline { 2 - 5 } & YCAI2 & 0,421 & 0,586 & 1 \\
\hline
\end{tabular}

Tab. 3. Correlation matrix between the variables used.

have the relationship between the gradient index of the geomorphologic area (YCAIP) and the Visual Dominion Index 1 (YCAI1) (0.212) (tab. 3).

Regarding the importance of the variables in the different components, we can say that in the first column the two visual dominion indexes 1 and 2 (YCAI1 and YCAI2) stand out as a positive value (0.79 and 0.886 ); in the second column we have respectively the gradient index of the geomorphologic area (YCAIP) (0.738) into the positive values and the Visual Dominion Indexes 1 (YCAl1) into the negative values (-0.497). Finally, in the third column we have these two indexes (YCAIP $(0,181)$ and YCAI1 (0.359) that appear to be the less relevant components (tab. 4).

The cluster analysis retained as valid all the cases examined. The analyses have divided the nuragic monuments into two distinct groups (Tab. 5): it appears immediately clear that the first cluster (fig. 4, a-b), consists of seven monuments located in altitudes varying from $41 \mathrm{~m}$ above sea level (such as the nuraghe Arratzu), to $84 \mathrm{~m}$ of the nuraghe Santa Barbara.

Most of these nuraghi have a very low index of Visual Dominion 1, which make them settlements 

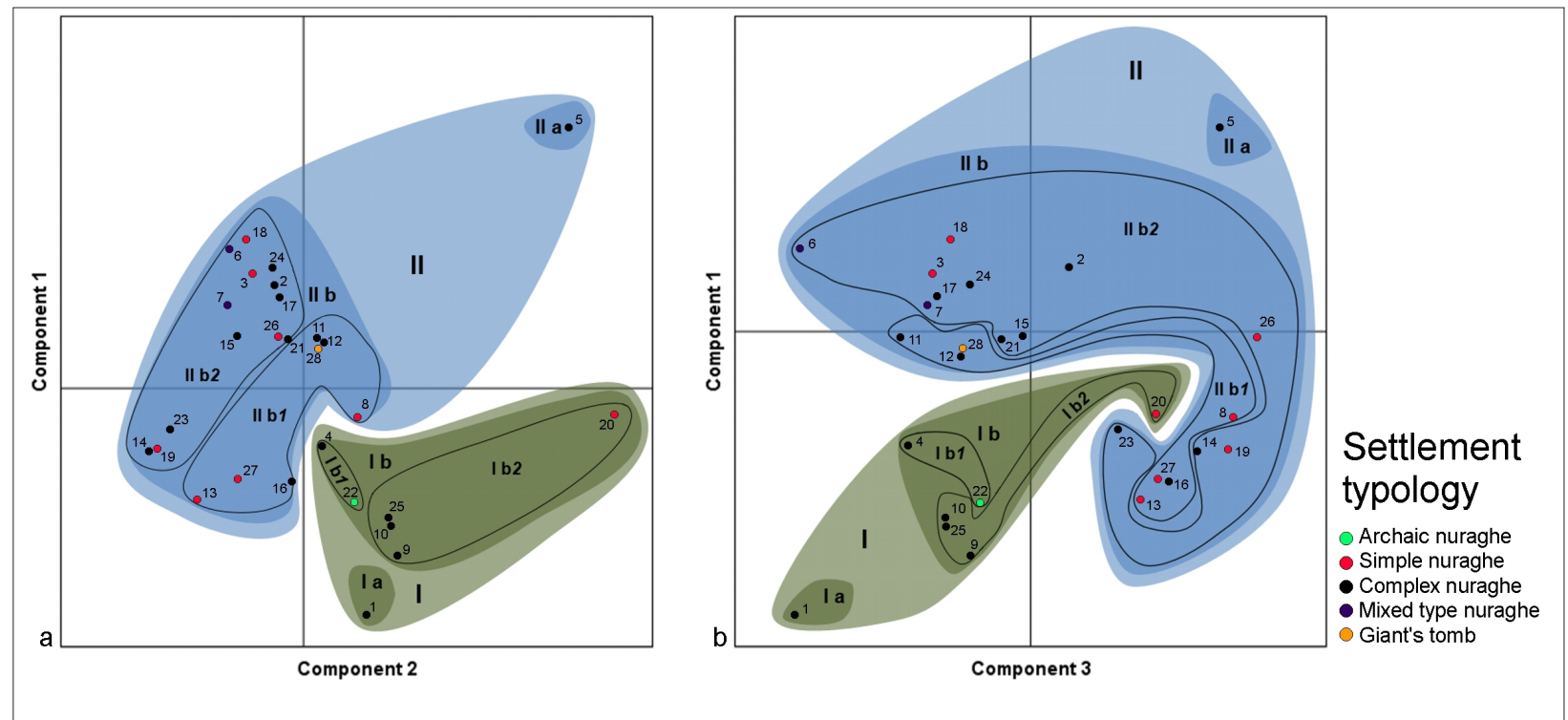

Fig. 4. Results of the main components analysis performed on the index of gradient of the geomorphological area (a) and on the visual dominion indexes (b).

\begin{tabular}{|l|l|l|l|}
\hline Group & YCAIP & YCAI1 & YCAI2 \\
\hline $\mathrm{I}$ & $0,008-0,177$ & $0,094-0,52$ & $1,13-1,89$ \\
\hline $\mathrm{II}$ & $0,006-0,248$ & $0,67-1$ & $1,13-3,21$ \\
\hline
\end{tabular}

\begin{tabular}{|c|c|c|c|}
\hline \multirow[t]{2}{*}{ Variables } & \multicolumn{3}{|c|}{ Component } \\
\hline & 1 & 2 & 3 \\
\hline YCAIP & 0,65 & 0,738 & 0,181 \\
\hline YCAI1 & 0,79 & $-0,497$ & 0,359 \\
\hline YCAI2 & 0,886 & $-0,098$ & $-0,453$ \\
\hline
\end{tabular}

Tab. 5. Values of the variables relating to the principal groups recognised by the cluster analysis.

consists exclusively of the nuraghe Cruccu (fig. 4 , a; b Quadrant NE), characterised by a high value for all three indexes that make it an ideal lookout. (Tab. 6-7) The subgroup "Ilb" contains all the monuments that have excellent indexes of visual

Tab. 4. Incidence of the indexes for each of the components.

whose preservation depends exclusively on the control of the other monuments built on the basaltic plain of Sa Struvina.

The analyses on this first group have recognised two subgroups (la and Ib), determined by an index of Visual Dominion 1 having a very low weight, and two types (I b1 and I b2) characterised by a good index of Visual Dominion 2, or by a discrete capacity to control the immediate territory but still limited by the nature of the territory, not particularly high, and by visual obstructions such as basaltic plains (tab. 6-7).

The second cluster, which includes $75 \%$ of the monuments that are the object of this study, is divided into two distinct subgroups: the "Ila" dominion (YCAI1 and YCAI2) and the gradient index of the geomorphological area (YCAIP) and that somehow have exploited to the best the morphology of the territory, such as the basaltic plains and the isolated hills, to amplify the visual capacity and to monitor the landscape. In this subgroup there are two "types" (fig. 4, a-b): in the set "Ilb1" we find all the monuments erected at average height and able to look at the surrounding flat area. We note, finally, that all the sites with very high indexes and wide-range visual capabilities have been grouped in the type "Ilb2", first of these, the complex of Cuccurada.

A.M. 


\begin{tabular}{|l|l|l|l|}
\hline Subgroup & YCAIP & YCAI1 & YCAI2 \\
\hline $\mathrm{I} \mathrm{a}$ & 0,008 & 0,094 & 1,24 \\
\hline $\mathrm{I} \mathrm{b}$ & $0,048-0,177$ & $0,28-0,52$ & $1,13-1,89$ \\
\hline $\mathrm{II}$ a & 0,248 & 1 & 2,68 \\
\hline $\mathrm{II} \mathrm{b}$ & $0,006-0,094$ & $0,67-1$ & $1,13-3,21$ \\
\hline
\end{tabular}

Tab. 6. Values of the variables relating to the subgroups recognised by the cluster analysis.

\begin{tabular}{|l|l|l|l|}
\hline Type & YCAIP & YCAI1 & YCAI2 \\
\hline I b1 & $0,048-0,177$ & $0,28-0,4$ & $1,13-1,39$ \\
\hline I b2 & $0,049-0,049$ & $0,43-0,52$ & $1,41-1,89$ \\
\hline Ilb1 & $0,006-0,092$ & $0,67-0,75$ & $1,13-2,47$ \\
\hline Ilb2 & $0,007-0,094$ & $0,85-1$ & $1,25-2,91$ \\
\hline
\end{tabular}

Tab. 7. Values of the variables relating to the the types recognised by the cluster analysis.

\section{Conclusions}

In conclusion, the integration of data obtained by different methodologies analysis allows us some considerations that are useful for understanding the mode of settlement in the territory of Mogoro during the proto-history. The topographic analysis related to the geomorphology of the area clearly shows the presence of a control system on the basaltic plains, consisting of nuragic buildings located in a strategic position with visual connection between them, to defend the economic wealth of the region and to guard the access routes towards the interior. The system is divided into three parts: the West line, the North East section and the South section.

It is interesting to note that many of these structures of the Bronze Age (Cuccurada, Su Guventu, Enna Pruna, Serra Sa Furca, Arrubiul arise in settlements already occupied during the Copper Age, in particular by people of Monte Claro culture: the strategic placement of these sites appear to correspond to a first organisation of territorial control in the Copper Age, used and expanded in proto-historic times.
The nuraghi located at the edges of the basaltic plains defended, in some way, what was in the highlands, probably pasture areas and perhaps even land that was suitable for hunting, as evidenced by the later bronze statuette of the Iron Age with hunting scene, from the nuraghe Cuccurada. As is evident from the GIS analyses, the structures on the edge of the plains also dominate the underlying territory, in visual contact with the nuraghi of the lowland, which are instead control centres linked to agricultural activities, practiced for a long time in these areas.

All the nuragic monuments of the territory in question therefore seem to be part of a unified set, in which each of the sites held a special function in connection with the others: they may be, therefore, settlements pertinent to a polycentric community united by kinship and collaboration, documented in other areas of Sardinia (Usai, 2003). The cluster analysis confirm what was visible with the geomorphological study: the data considered, in fact, clearly divided the proto-historic sites of this area into two main groups: the first pertinent to settlements with a medium or low index of visual dominion, while the second, more numerous, which includes the nuraghi placed in an elevated position with strategic control.

The control of natural resources and above all of the communication ways are also confirmed by the GIS analysis: the two settlement types highlighted, the one on the plateaus and that in the lowland, which are closely interrelated, together constitute a territorial control system of medium size, connected to other neighboring systems.

During the phases of the Middle and Late Bronze Age this part of Sardinia shows a widespread distribution that denotes a systematic control of the territory. The strong intervisibility found demonstrates the wish of the proto-historic people to keep tight control all areas economically important, such as transit routes, pastures and arable areas.

R.C. 


\section{References}

Atzeni E, R Cicilloni, G Ragucci \& E Usai 2001: Il complesso megalitico pre-protostorico di CuccuradaMogoro (OR), in Serreli G \& Vacca D (ed.), Aspetti del megalitismo preistorico: 31-35. Grafica del Parteolla, Dolianova.

Atzeni E, R Cicilloni, G Ragucci \& E Usai 2005: Notiziario. Nuraghe Cuccurada (Mogoro, Prov. di Oristano), Rivista di Scienze Preistoriche, 55, 557-58.

Camerieri P \& T Mattioli 2013: Obscura itinera: a GISbased approach to understand the pre-Roman and Roman transhumance pathways in Umbria and Sabina regions (Central Italy), in Earl G, Sly T, Chrysanthi A, Murrieta-Flores P, Papadopoulos C, Romanowska I \& Wheatley D (ed.), Archaeology in the Digital Era. Papers from the 40th Annual Conference of Computer Applications and Quantitative Methods in Archaeology (CAA), 26-29 March 2012 Southampton: 332-39. Amsterdam University Press, Amsterdam.

Casarotto A, A De Guio \& F Ferrarese 2009: Action GIS: Un modello predittivo del movimento antropico in un paesaggio antico. Il caso di studio archeologico della Val D’Alpone (VR), Archeologia e Calcolatori, 20, 291-307.

Cicilloni R, 2007: Il nuraghe Cuccurada di Mogoro (OR) nel contesto archeologico dell'alta Marmilla, in Angiolillo S, Giuman M \& Pasolini A (ed.), Ricerca e confronti 2006. Giornate di studio di archeologia e storia dell'arte: 35-41. AV, Cagliari.

Cicilloni R, 2014: Nuova figurazione antropomorfa di cultura Ozieri da Serra Neula/Puisteris-Mogoro (OR), Archeoarte II (2013), 31-41, viewed 8 February 2015 , http://ojs.unica.it/index.php/archeoarte/article/ view/1256

Conolly J \& M Lake 2006: Geographical Information Systems in archaeology, Cambridge university press, Cambridge.

Gherdevich D, 2009: L'analisi spaziale come strumento per la ricostruzione della viabilità antica del Friuli Venezia Giulia, PhD Thesis, University of Trieste.

Hodder I \& CR Orton 1976: Spatial Analysis in Archaeology, Cambridge University Press, Cambridge.

Hodson FR, 1969: Searching for Structure within Multivariate Archaeological Data, World Archaeology, 1 , 1, 90-105.
Lilliu G, 1988: La civiltà dei sardi dal Paleolitico all'età nuragica, Nuova ERI, Turin.

Melis MT, 1998: La ricostruzione paleo-ambientale come strumento di indagine archeologica, in Tanda $G$ (ed.), Sedilo. I monumenti. Tomo III. I monumenti nel contesto territoriale comunale: 9-20. Soter, Villanova Monteleone.

Pecere B, 2006: Viewshed e Cost Surface Analyses per uno studio dei sistemi insediativi antichi: il caso della Daunia tra X e VI secolo a.C., Archeologia e Calcolatori, 17, 177-213.

Spanedda L, 2006: La edad del bronce en el Golfo de Orosei (Cerdeña, Italia). PhD Thesis, Universidad de Granada.

Spanedda L \& JA Cámara 2007: El patrón de asentamiento nurágico en el municipio de Dorgali. El análisis de los centros habitados, Revista Atlántica-Mediterránea de Prehistoria y Arqueología Social, 9, 91-141.

Spanedda L, JA Cámara \& ME Puertas 2007: Porti e controllo della costa nel golfo di Orosei durante l'età del bronzo, Origini, Preistoria e Protostoria delle civiltà antiche, 19, 119-44.

Spanedda L, JA Cámara \& FE Salas 2010: Bronze Age settlement patterns in Dorgali municipality (Sardinia), Rivista di Scienze Preistoriche, 60, 283-306.

Usai A, 2003: Sistemi insediativi e organizzazione delle comunità nuragiche nella Sardegna centro-occidentale, in Le comunità della preistoria italiana. Studi e ricerche sul neolitico e le età dei metalli, Atti della XXXV Riunione Scientifica IIPP, Lipari 2-7 giugno 2000: 215-24. Istituto Italiano di Preistoria e Protostoria, Florence.

Wheatley D \& M Gillings 2002: Spatial technology and archaeology. The archaeological applications of GIS, Taylor and Francis, New York. 